\title{
YALE
}

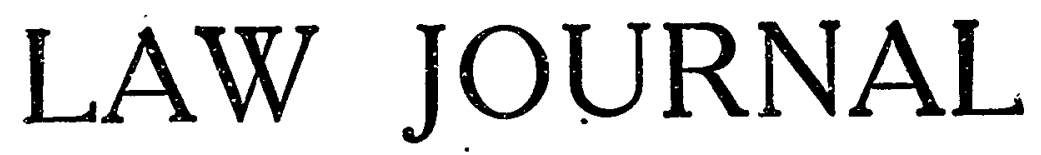

\begin{tabular}{lll}
\hline \hline Vol. XXXIV & MARCH, 1925 & No. 5 \\
\hline \hline
\end{tabular}

\section{DANGER-SIGNALS IN INTERNATIONAL LAW}

\section{T. BATY}

\section{INTRODUĊTION}

The international lawyer, taking stock of the position as it stands, will be less impressed by the fact that occasional gross violations of the law were committed in the course of a world-wide war, than by the fact that a notable dry-rot has crept into fundamental departments of its content It seems to be nobody's concern to maintain in their integrity principles which are really vital to the association of free states as we have hitherto conceived it.

Partly, it seems, this is due to the excessive devotion of conferences to the elaboration of details and the amplification of codes, which are put forward solemnly for the acceptance of the nations. When these elaborate provisions prove ambiguous or unworkable, or when a coach and horses are driven through them, under the stress of war, as inevitably occurs, the unthinking cry is raised that international law is a broken reed. And the real law of nations, which is not written in the text of a polynational convention, but in the hearts of civilized and instructed people, suffers accordingly; its authority is appreciably weakened. It is the great glory of international law that it is free and elastic. No despot or demagogue enacts it; no academy or professor settles it. Legislatures are its subjects and not its creators. It rests on the common instructed opinion of the people. Not even majorities can make international law.

To be grasped by common instructed opinion, and to find its sanction in the hearty support of that opinion, international law must be simple. It must rest on broad principles appealing to the universal conscience. It must not involve, as municipal statutes may, the interpretation of dubious texts or the application of scholastic subleties. It cannot be elaborate, qualified, obscure. It must be clear, simple, succinct. 
There are three points in which the very basis and foundation of international law is being quietly sapped to-day. One concerns the Land. One concerns the Sea. . One concerns the Pledged Word.

\section{The Land.}

It is, or was, the fashion to say that territorial independence has been the foundation of the law of nations since the Treaty of Westphalia. In fact, it has been its foundation from a much earlier period. Complicated as were the relations of states under the feudal system, they were never complete. No pope or emperor ever succeeded in imposing a universal supremacy on the world. Some vassals could readily be crerced and invaded. But there were vassals who could not. An assault on them, however loudly declared to be an execution, could not fail to be regarded as a war. The sense of sacredness of national soil liong antedated the magic year 1648 .

Nor have feudal relations, since $I 648$, ceased to have practical importance. It is sufficient to mention the word "Schleswig-Holstein." Yet it is true to say that since $I 648$, the world has been patently and formally organized on a basis of territorial independence. The attempt of the Reich to act as an earthly providence-as some would install an earthly providence to-day-was in that year definitely checked. Austria would have kept the mass of Europe Catholic-the only safe and sane religion for civilized humanity, according to Austria-the only guarantee of safety in this world and reasonable prospects for the next. It was too much. Protestantism had to live: and as Austria would not let it live, it had to proclaim the independence of the land. Austria and the Reich failed. The treaty of 1648 set the seal on its failure. Absolute territorial independence, even to the deepest things of the soil, this was thenceforward the admitted keystone of international relations. Cujus regio, ejus religio.

One may pause to say that in speaking of absolute territorial independence, one is speaking in terms of common sense, and not of mathematics. The independence of the territorial sovereign was not, of course, mathematically infinite. Limited by his engagements, limited by the common opinion of humanity, it undoubtedly was; and it is precisely because no one of any moderate intelligence is in any danger of thinking otherwise, that we can safely call it absolute.

Since 1648 , then, in formal theory, and for centuries before, in reality, territorial integrity has been the foundation of the international system. We have as its postulate a series of states, none of which has any right to exercise force within the limits of another.

Now it must be frankly admitted that this society of free nations is not exempt from the law of change. It can, and must, no doubt, be modified with changing thought. The process is a gradual and natural one: it may well be so directed as to be a desirable one. But what is 
threatening at present is that the system will be swiftly and irreparably destroyed, without any substitute being evolved to take its place; and the result will be sheer anarchy. This sounds like the wailings of Cassandra, but really Cassandra should have been listened to! Thirty years ago, the tremendous consequences to the rights of neutrals implicit in the then heretical doctrine of continuous voyage were commonly treated as interesting academic exercises, and it was almost impossible to get people to realize what serious developments might come of it, until they were confronted with the accomplished fact in the recent war. Cassandra was smiled aside.

For the present, the welfare of the world is bound up with the independence of the nation. We may have hopes and dreams of a much superior world state, but unless and until it is ready, we shall be foolish if we destroy the world-organization of independent states which we all more or less understand and accept. We shall simply get a welter of uncertainty and anarchy.

What has been clear and simple to everybody for centuries and generations, has been the elementary principle that no nation can cross the boundaries of another with armed force, except with its consent, or in open war. If it makes the invasion it accepts all the consequences. It cannot have it both ways-proclaim peace and exert force. Its acts speak louder than its words. The possibility of attacking a nation, and at the same time being at peace with it, was never regarded seriously. The consequence was that territorial integrity was exceedingly well safeguarded. Every nation, from the smallest to the greatest, knew that it was safe within its own borders, unless some other chose to incur the responsibility before the world of going to war with it. The stability which this certitude gave to the international system can hardly be overrated. War is an eventuality which no nation can lightly incur. It disturbs the world's peace and renders everybody apprehensive and uneasy. The loss to the belligerent must always be considerable in life and treasure. The weakest enemy may find unexpected allies. Surprises may be in store-Greece may hurl back Persia; Holland the Empire; Revolutionary France the world. Moreover, the belligerent can receive no atom of countenance from any neutral; not an ounce of powder or a single gun, nor leave to use its harbors as bases. War is a serious undertaking. And short of a disposition on the part of its adversary to embark on war, nothing could make a nation unsafe at home. Even in the wild days of the French Revolution and the Napoleonic Wars, and in the anomalous case of the Ottoman Empire, the rule of territorial integrity has been very well observed.

This principle, firmly valid right up to our own days, has decayed, is decaying, and will continue to decay if nothing is done to stop the rot.

We shall find, in the place of our coherent and firmly-knit states, a congeries of amorphous organisms from which each one tears such pieces as it can snatch or nibble, and to which each dictates as loudly 
as it dares, with the threat of violence, clashing madly with the violence of the rest. In short, flat anarchy.

The principle of the absolute inviolability of the soil was so fundamental and unquestioned that it never entered the heads of statesmen to think of infringing it. It was one of the things which simply "were not done." It would be universally regarded as an act of war, and no one could hope to induce other nations to believe it to be anything else. When Louis XIV announced his intention of invading the Low Countries "sans que le pais soit rompue de notre part," everybody laughed at him. It was an arrogant absurdity.

In the course of the French Revolution wars many unlawful things were done. But the pretension to put armed pressure on a state while remaining at peace with it, was seldom or never advanced. Nobody doubted that the impudent attack of Canning on the Danish fleet and the bombardment of Copenhagen was an act of war. When Campbell makes the British Admiral say-"But yield, proud foe, thy fleet," he certainly did not mean to say- "Proud friend." Napoleon's troops may not have been very respectful of neutral frontiers when pursuing their enemies, but their pursuit, reprehensible as it undoubtedly was, was in no sense directed against the neutral power, or intended to put pressure upon it. Nor were the lawless kidnapping of the Duke of Enghien and Sir George Rumbold of sufficient magnitude as operations to be styled "war."

The first real modern instance of what has been elsewhere called "the Ludovician heresy"-Louis XIV's pretension that one state can invade another without going to war with it-does not meet us until 1895 . The French invasion of the Morea in 1828, when French and Turkish troops fought battle after battle, was undoubtedly war. Antonelli characterized the Austrian invasion of the Papal States in I848 as war, and it is difficult to see anything but war in the Brito-Franco-Spanish expedition of $185^{8}$ to Mexico; it had exactly the same character as the prolonged French operations which succeeded it, and which certainly constituted a war between Mexico and France. The French expedition to the Lebanon in $185^{\circ}$ had the reluctant consent of Turkey. The British operations in Egypt in I882 were justified as undertaken in support of the Khedive's government against a military dictatorship. The Russian occupation of the Principalities in 1853 was the occupation of a Russian protectorate with the hearty assent of its population.

By the end of the nineteenth century, the principle of the absolute sanctity of the national territory and the assurance that it could not be invaded without war, avowed or implied, had become axiomatic. One or two bombardments, somewhat consciously cited" as "occupation of territory," are of no importance in this connection. They were quite anomalous, and occurred because there was no recognized power who

${ }^{1}$ (1924) I8 Am. Jour. INT. L. 99. 
could effectively control the bombarded place. And then the enchanter waved his wand and broke the beneficent spell. The enchanter was a respectable British nobleman called Wodehouse.

John Wodehouse, Earl of Kimberley, was Foreign- Secretary of Great Britain because a really great diplomatist, the Earl of Grenville, had been made impossible by the misfortunes of $\mathrm{Mr}$. Gladstone in foreign affairs. He had always wanted to be Foreign Secretary, but his most remarkable diplomatic employment had previously been on a special mission to Copenhagen to settle the Schleswig-Holstein question, in which endeavor he had been somewhat conspicuously unsuccessful. He now in 1895 marched British marines into Nicaragua, and took possession of Nicaraguan territory (including the Custom House at Corinto) as a means of collecting a small sum ( $\left.\varepsilon_{\mathrm{I}} 5,000\right)$ from the government. They stayed a few days, and went away with the money, or at any rate with a promise to pay it.

This, it may be considered, was the crucial act by which the bulwarks of territorial security were breached. If by the example of the power claiming to be among the fore in the civilized traditions of centuries, any state could walk in at another's front door and help itself to the plate and china in satisfaction of its real or fancied injuries, then every weak state becomes the happy hunting-ground of those who consider themselves stronger, and the only precarious security remaining is their forbearance and their mutual jealousies.

War had been the recognized litigation of nations. Now there was added burglary.

Parenthetically I may add, as a municipal lawyer, that I do not see any defense that could be urged to an indictment for burglary or housebreaking against a foreign admiral who should embark on similar steps, if they are compatible with peace. If the king of the United Kingdom, having a claim against the United States, should instruct his admiral to slip in and snatch the amount from a New York bank in peace time, I cannot conceive that an indictment would not lie against the gallant officer if he obediently complied. If the bank-snatching admiral is amenable to the criminal law-and one thinks he must bethen the custom's house-breaking admiral must no less be so. Only the fact of war could save him, and the absurd hypothesis is that there is no war. The instructions of an officer's sovereign are a perfectly good defense in war, but I have never heard that by the common law they are a good defense to upsetting the public order of a country for his sovereign's purposes on any other occasion. However, that is parenthetical. The British marched into Corinto, and got away with the goods.

Why this unheard-of and violent proceeding was resorted to by Lord Kimberley, who was a mild-mannered gentleman, and not prone to extravagances which would have shocked Disraeli or Palmerston (to say nothing of Peel and Aberdeen), has always been mysterious to me. 
He wanted the $£_{15,000}$ as compensation for a knot of Englishmen who had been expelled from Bluefields. The rights of Nicaragua in Bluefields which is Greytown, and the rights of Great Britain to interfere there, were eminently doubtful and delicate matters, depending on the construction of a particularly obscure treaty.

Five years previously Lord Salisbury had consented to refer just such problems to Austrian arbitration, and had had no reason to regret the result. Why could not Kimberley have done the same? The whole affair remains an insoluble mystery. We cannot even say that the unworthy practise of so-called "pacific blockade" furnished a precedent. "Pacific blockade" is a bad enough solecism;" but there is a great difference between seizing ships and occupying a port. Nor was there apparently any regard paid to the Monroe-Polk doctrine. It had not yet become fashionable in Europe to profess a high regard for the MonroePolk doctrine, but it was only a few months later that President Cleveland brought it prominently forward in connection with Venezuela. True, no permanent acquisition of Corinto was for a moment contemplated by Lord Kimberley, but the territorial status of Bluefields was gravely concerned. It is all a considerable mystery, the more mysterious in that Nicaragua was almost immediately allowed to abolish the anomalous "Mosquito Indian" autonomy of Bluefields and to incorporate the territory into her complete and independent sovereignty.

Perhaps, in crediting Lord Kimberley with this new and startling development, we scarcely do justice to $M$. de Freycinet. As early as I885 this statesman had, in the course of his demands upon Siam, occupied the island of Chantabun, at the mouth of the Menam, leading to Bangkok. As, however, his ships and troops at the same time threatened the capitol and embarked on brisk engagements with the royal forces, in the course of which many persons perisined, it seems to us that it would be extremely pedantic to represent the proceedings as "limited violence" or as anything but war, and the French did nothing to disclaim the name, though matters were soon accommodated with the Siamese. Two years earlier, M. Jules Ferry had repudiated the idea of war, when battering forts and sinking junks in China. But nobody, least of all the British Foreign Office, agreed with him.

The new idea of peacefully pouncing with guns on your neighbor's land, like all great and simple discoveries, was not long in spreading. Before the end of the century, we see Germany in Kiaotshao, and the Six Powers in Crete, which is quick work. Again, in I9oI France had a petty and sordid little dispute with the Porte about quays at Constantinople. She clinched her argument (it was M. Delcassé, the

\footnotetext{
2 "Does the honorable and learned gentleman suppose that he can take the ships of another Power and blockade its ports without a state of war? Evidently a blockade does involve a state of war." Lord Balfour, in6 Hansard, Parliamentary Debates (4th series, Ig02) I49I.
} 
reader will not be surprised to hear) by landing troops at Mitylene and occupying the island. ${ }^{3}$ The Six Powers in 1897 found Mohammedans and Christians at loggerheads in the Turkish island of Candia; they stepped in and administered the island themselves. Their excuse was that Greece would otherwise have attacked it, and that a Greco-Turkish war would thus have been occasioned which might have led to a European one. As a matter of fact, the anticipated Greco-Turkish conflict was not prevented. The occupation, which was begun in 1897, mainly to prevent the incursions of Greeks, ended two years later in wresting the control of the island completely from the Sultan. The twentieth century has seen conspicuous examples of disregard for territorial integrity at the expense of Greece. Allied troops occupied Salonica for their base; and dumped Servians into Corfu as a reservoir. Infection spreads. In I923, having a claim against Greece on account of the assassination of official Italians in Albania, the Italian government proceeded to invade the Greek island of Corfu, with force and violence, bombarding the forts and entering upon a drastic military occupation.

With every possible respect for the Italian Government, which is carrying out a great work under great difficulties, this was an encouragement to international anarchy which ought not to have been afforded. If Italy thought Greece was really denying her justice, she could have arbitrated, she could have seized Greek public property in Italy, or she could have declared honorable war. For a strong nation to batter down a weak one's cities, and to kill her people, calculating that she will have no choice but to pocket the insult, is to head good and hard for anarchy. The common sense of the world expressed itself with considerable clearness in that scene, and the lamentable incident has perhaps on the whole been productive of good, in securing that emphatic and universal pronouncement. But an oracular deliverance was made by the juristic commission which was entrusted by the League of Nations with the duty of reporting on the legal bearings of the incident, which contains the seeds of infinite trouble.

They are said to have pronounced formally that "There may be occasions on which one nation may invade the territory of another without war." It seems to me that this formal and clear pronouncement is certain to give encouragement to invasion, and ultimately to introduce a laxity into practice which will be fatal to settled order among the nations. It is true that self-help is permissible in cases where the apprehended injury is very great, the violence employed comparatively small, and no possibility exists of warding off the danger through the orthodox channels; where, as Webster said in the Carolina case, the circumstances are so "instant and overwhelming" as to allow "no choice of means and no moment of deliberation." But this is not invasion, it is simply doing with the presumed consent of one's friend what there

3 (1902) 9 Rev. Gen. de Droit Int. Pub. 677. 
is not time and opportunity to obtain her express consent for. It does not apply to action taken openly against her will, or intended to coerce her into compliance with one's own.

For instance, we are sure that few unprejudiced Americans will deny that the action of General Andrew Jackson in attacking the Spanish garrisons in Florida cannot be supported as instances of self preservation. Where there is a responsible officer of the foreign government who declines to remove the source of danger, his forcible coercion can only take the shape of war. Nobody can think that the gallant general, carrying fire and sword into Spanish territory, capturing Spanish forts and Spanish captains, was a purely peaceful phenomenon.

But it really is not this most exceptional and anomalous right of selfpreservation at all of which the learned jurists were thinking. If it were, it should not have been mentioned without the strongest warning as to the extraordinary circumstances which alone can justify its exercise-fatal urgency, comparative innocuousness, and ample apologybut it really was not that at all. It was the academic, pedantic heresy that, war implying the intention to make war, if the invader disclaims the intention, there can be no war unless and until the invaded declares it. This is a fallacy.

The fallacy lies in identifying the intention of the invader with the expression of his intention. If he says he does not want to make war, if even sincerely he says he does not want to make war, it cannot alter the fact that he is making war. The fact of entering ancther country with armed force, prepared to overcome with violence any governmental resistance, is nothing else but war, whatever one chooses to call it. Even the upholders of this strange fancy that an invader can evade the consequences of the war he is waging, by the simple process of saying that he does not want them, are driven to admit that when an actual collision occurs, it is hard to say that the countries which are fighting are not at war.

No support can be obtained for this fancy from the great authorities. Grotius certainly defines war as the relation between two states "per vim certantiorem"-contending by physical force-but it is certainly unnecessary for any actual force to have been used, in order to create a state of war. It is a definition, which cannot be pressed. to mean that war is not war until both sides are actually fighting.

It is surprising that the notion of "pacific" seizure of territory should be justified under the head of "reprisals." This is catching at straws. No student of international law, who is familiar with the sort of thing covered by "reprisals," could ever imagine that it could be extended to such acts as the seizure of the national territory. Reprisals were fast becoming obsolete, as relics of a barbarous age. They certainly meant self-help; but they were always limited to self-help within one's own dominions or on the high seas. They never touched the vital nerve of 
state-life. W. E. Hall, indeed, goes so far as to say that "anything" is permissible as reprisals, provided there is sufficient cause for them. ${ }^{4}$ He infers this from the fact that reprisals are an alternative for war, and he appears to argue, with amazing fatuity, that because extreme violence is permissible in war, subject to all its risks and responsibilities, therefore all but extreme violence-"complete war"-is permissible in reprisals, subject to no risks or responsibilities whatever! He gives no example of invasive reprisals, and it is obvious that his whole argument is advanced by the influence of his naive assumption that because the greater includes the less, therefore any one-sided violence is justified as a substitute for two-sided war. If that had really been so, what curious "reprisals" the world would have seen in the course of its strange history!

As a matter of historic fact, reprisals are strictly limited to acts accomplished within one's own territory and on the high seas, and are practically limited to seizures of movable property. It is a grotesque perversion to make them cover invasion and occupation. Bluntschli, according to Woolsey, enumerates the following forms of reprisals,and it will be seen that none of them is of any sweeping extent. ${ }^{5} \mathrm{Had}$ others been resorted to, he could not have failed to mention them in this elaborate analysis:

I. Seizure and sale of the offender's property found within the territory of the injured state.

2. Seizure of private property of persons belonging to the offending state, (providing the latter has unjustly seized property of persons belonging to the injured state).

3. Stopping communications.

4. Expelling or excluding persons belonging to the offending state within the territory.

5. Keeping representatives or subjects of the offending state as hostages.

6. Imprisonment of officials or citizens of an offending state in requital of the same conduct on its part.

7. Refusing to fulfill agreements or treaties.

8. Depriving subjects of the offending state of privileges or protection in matters of private law.

This enumeration by a master shows what was universally understood by reprisals. Heffter, defining reprisals as "all forcible means which a government uses towards another state, its subjects or property belonging to the latter, with the object of" securing satisfaction, by no means implies that any and every violence is open to governments under that head. He divides reprisals into $(I)$ the suspension of engagements, (2) the suspension of friendly intercourse, (3) seizure and sequestra-

'Hall, International Law (6th ed. rg09) 363.

${ }^{5}$ Bluntschli, Das Moderne Völkerrecht (1878) sec. 500. 
tion of persons and property. ${ }^{\circ}$ Calvo (sec. I8II) mentions casually "détention des territories"-but he gives no authority or examples. Calvo's treatment of the whole matter exhibits the continental mind at its worst; he is apparently willing to allow of any limited violence as reprisals, but he requires that the acts complained of $i$. shall have been manifestly contrary to all reason and justice. ${ }^{?}$ Of course a state which wishes to exercise reprisals will say, thus encouraged, that the wickedness of its opponent was manifestly contrary to all reason and justice: and it will be exceedingly difficult to contradict it. The whole discussion is thus removed to the region of subtleties and opinions, and all definite security disappears. Calvo, thus, in effect, encourages what he terms "the revolting abuse" of reprisals exercised on grounds satisfactory to the state alone which exercises them. Hall's quaint idea that nations may pull each other to pieces without war, so long as they are careful to call their acts "reprisals" may be dismissed as the fantastic aberration of a declared advocate of the policy of providing strong states with alditional weapons against weak ones.

It is also a delicious example of the danger which besets the most practical persons of enunciating a theory without the slightest reference to practice. "Reprisals," says the American Woolsey, "are inhuman, and . . . will, it is hoped, ere long, entirely cease."8

Despagnet and de Boeck rightly declare that when so-called "reprisals" which take the form of bombardment, as in the case of Foo-chow by France in 1885 ; or the occupation of territory, as in the case of Corinto by Great Britain in 1896 , it is very difficult to call them anything but war. They apply the same criticism to the bombardment of Fort San Carlos in Venezuela in I902, and to the occupation of Mytilene in IgoI. "The essence of war," they observe, "is the employment of force to support one's claims." And in any case, they point out, the modern law of nations does not permit private persons to be put to death under the head of "reprisals," much less, it may be inferred, can they be put to death wholesale, by bombardment or by forcible invasion which as patriots they cannot but be expected to resist.

The idea of pacific war is, in its origin, nothing but another branch of that pestilent doctrine of intention which has worked so much havoc in the law of nations. The law of nations imperatively requires to be simple, clear and objective. It must take account of facts, and obvious facts at that. It has not the machinery and apparatus for examining delicate questions of intention. Academic theorists, who see every day questions of intention discussed and decided in the courts, are prone to commit the mistake of imagining that the law of nations, devoid,

'Heffter, Droit Int. de l'Europe (I883) sec. Iro.

${ }^{2}$ Calvo, Le Droit International (1896) sec. I8r3.

${ }^{8}$ Woolsey, International Law (I874) sec. II8. 
and necessarily devoid, of all the apparatus for the purpose, can afford to become as speculative and subjective as municipal law, and are prone indeed to go to lengths in attaching importance to intention of which municipal law would never dream. All that international law can properly assess is the obvious intention of the invader to get his way by force-this in itself, coupled with the overt facts, is war. Whether there exists along with this intention a further intention to avoid its legal and normal consequences is a matter of perfect indifference to anyone who has not erected subjective intention into a fetish.

It will be said that the invaded party can always declare war if he chooses. But the point is not that the pacific declarations of the invader make it impossible to resist him, but that by trading on the weakness of the other party, he obtains all the advantages of war without any of its embarrassments, risks and losses. Constitutional difficulties might have held him back from war-they are avoided. Neutral scruples might have deprived him of the means of war-they are dissolved. An enemy might have found unexpected strength, or unexpected allies-there is no enemy, only an important victim. Such a possibility is not creditable to civilization, nor to common sense. That an invader cannot wage a war, the upshot of which may be a slight adjustment of boundaries, without incurring a whole chapter of embarrassments, whilst he may without the slightest check "pacifically" occupy and annex a kingdom, is a situation worthy of the ironic genius of Ring Lardner or W. S. Gilbert.

Such a state of affairs is self-condemned as irrational. It is also unfair to neutrals. Neutral obligations are now so heavy that a clear line of demarcation must necessarily be drawn between peace and war. But if a country may be invaded in peace-time, the line between peace and war will become impossible to draw. It will depend on the exact mental attitude of one or another of the two parties, and at this neutrals can only blindly guess.

Not only is the notion of peaceful invasion unfair to weak states, but unfair to neutrals. It is the parent of anarchy. If one state pecks at a weak state, others will peck too. Gradually we shall see the pecking simultaneous, and the peckers will begin to peck each other; cannot, in fact, avoid doing so. That there is no war involved will encourage them all in their violent courses, and a welter of anarchy, whether we write it down as "war" or not, will supervene, in which the system of independent states could by no miracle survive. In the meantime, some council of jurists would no doubt be usefully employed in telling the various nations which of them were aggressive.

The great hope for the peace of the world is that war shall at all costs be outlawed, as private vengeance has been outlawed. But what is the use of outlawing war, if violence is to proceed unchecked so long as it calls itself "pacific"? The first essential of peace is to secure that no nation, whatever happeris, shall cross the boundaries of another, includ- 
ing the bulwarks of its ships on the high seas. We are asked to contemplate the possibility of outrages being committed abroad for which we could get no redress. That is a risk which, it seems to me, it is worth taking. Provided that all nations are really (and not on paper) agreed to outlaw any country which, for whatever reason, crossed the frontiers of another with armed force, each state might be well content to let its neighbors do as they pleased within their own boundaries. But there must be no mistake about the permissibility of pacific bombardment. I venture to suggest that the word "not" be inserted in the Report of the Committee of Jurists on the Italo-Grecian question.

It is needless to say that these remarks have no application in the case where the territory in question is not under the sway of any definite government, as, for instance, when an empire breaks up, and no settled government exists in parts of the territory formerly subject to its rule.

\section{The SeA.}

It is common knowledge that the idea of continuous voyage, coupled with extravagant extensions of the category of contraband, has for the moment rendered the idea of blockade obsolete, and has made it practically possible to interdict all trade with the enemy. The position is exactly analogous to that which obtained at the end of the Napoleonic Wars, when the illegalities of both sides exercised towards neutrals had apparently swept the law of nations away altogether. We may derive considerable consolation from the fact that in a few years the law of nations reasserted itself, and was better and better observed as the nineteenth century wore on, until everybody was (say in I895) under the comfortable impression that the belligerent was an international. nuisance who would never be permitted to do very much harm; who would, like the Allies in I854, be very generous to his adversary's commerce; who would certainly be very strictly confined by neutrals to the narrowest interpretation of his rights as a blockader and a contrabandsearcher. Modern war was civilized and humane. The world's commerce was no longer likely to be allowed to be interrupted by noisy disputants. Ships would seek the enemy's fleet, and would not be particular about his merchantmen, still less about worrying neutrals. The neutral world would stand no nonsense. When unsettling problems were propounded, they were accordingly discussed in an atmosphere of comfortable consciousness that the discussion was academic. They would, one felt, all be resolved against the belligerent. The belligerent nowadays, was a nuisance.

We did not know exactly what was contraband and what was not. But we knew that contraband was ejusdem generis with shot and guns and saltpetre, and we felt that the growing disapprobation of war in the civilized world was quite strong enough to ensure that the list would be kept down, if not cut down to Hautefeuillan limits, which was per- 
haps more likely. When we turned our attention to the enormous possibilities latent in the Chase theory of continuous voyage, again we felt easy about the matter. After all, what was there to worry about? It was a new and alarming dogma-this of setting a prize court to guess at intentions, and condemn right and left as they guessed, under difficulties from which a municipal court is free. But it was rapidly receding into the distance. It had been applied in no more than three cases. It was the decision of five judges, and those not the most experienced, to four. American writers were perhaps on the whole against it. English writers styled its application "unfortunate violence." It was in flat opposition to the Scots case of the Stavorse Lynbaam. ${ }^{9}$ Doctrinaire continental pundits who accepted its impractical reliance on intentions, at the same time sternly insisted on a very rigid refusal to allow intentions to be the condemnation of anything but shot and shell and the like dangerous munitions. Britain had taken no step to lead anyone to believe that she accepted the new dogma. It is often asserted that she led, but that is an entire mistake. It may be that it was quietly realized at the Foreign Office that it would prove an exceedingly comfortable doctrine for a strong maritime nation some day; but no overt word or act evinced the surmise. The claims of the owners of the ships and cargoes concerned were duly supported, and referred in the end to the arbitrament of the High Commissioners at Washington, who disallowed them without any reasons being assigned, as part of the general settlement then made, and not improbably as part of a compromise.

Nothing was settled, and by 1895 it had never been suggested that Great Britain had adopted the doctrine. Westlake, with his continental proclivities for impractical theory, was inclined to favor it. Hall was uncompromisingly against it. Twiss showed cogently and rationally how it was going to revolutionize the position of neutrals. Dana and Evarts (if I am right) opposed it and Woolsey was very dubious. The general American attitude of upholding neutral rights seemed to overbear the approval of Bancroft Davis.

Then came a succession of thunderclaps, which ought to have reminded the world that it does not do to rest on one's oars and watch the millennium coming. "The price of our liberties is eternal vigilance." And nobody appeared vigilant. The first explosive aroused no attention whatever. Italy, at war with Ethiopia, captured a Dutch steamer -the Doelwyk-going to a Red Sea neutral French port. The prize court condemned the cargo as contraband taken on a voyage to the enemy. The appeal court released it on a technicality, peace having been concluded. Obviously there was nothing left to quarrel about, and the incident attracted very little attention in English-speaking

\footnotetext{
-The Stavorse Lynbaam v. Cap't Harden (Mar. 3, I76r) 4 FoL. DEC. I44; Baty, Scottish Prize Decisions of the Seventeenth and Eighteenth Centuries (I918) 27 YALE LAw JournaI, 453, 472.
} 
countries. Then at the very end of the century came the Lorenzo Marquez cases-the Bundesrath, General and Herzog ${ }^{10}$-in which German ships were stopped and searched on allegations of taking contraband to a neutral Portuguese port for the Transvaal during the war between Great Britain and the South African Republic. Germany protested, and Lord Salisbury in the end released the ships and paid an indemnity. This, however, was the occasion of a definite invocation by Great Britain of the principle of continuous voyage. She failed to make it prevail and it seemed to be hopelessly discredited. She had recoiled from asking the opinion of her own prize court upon it; she had given Germany satisfaction for acting upon it.

But five years later came the Russo-Japanese War. And it was seen at once that trouble would arise. The Ethiopian and Transvaal wars were not maritime wars. Now a great maritime war was in progress, and Russia went boldly ahead in pushing neutral claims aside. It was seen with surprise and disquiet that it was the belligerent, and not neutrals, who was getting her way. One reason for this was that Great Britain was in the throes of a general election, and one of a particularly crucial kind, which resulted in the overthrow of the Tory domination of some twenty years, the crushing defeat of protection, the healing of the chasms created by Home Rule and the Transvaal war in the Liberal party, and its triumphant advent to power with a deadly earnest desire to do things. Domestic politics filled the public eye. The continent was, on the whole, sympathetic to Russia; and the United States had the presidential election of 1904 in hand, besides having no great injuries to complain of.

The Russian action threatened neutral rights in three ways: the list of contraband was extended to such things as cotton, the doctrine of continuous voyage was applied, and suspected neutral ships were sunk. The extraordinary thing is that next to no notice was taken of all this by the great public in the west. When the Russian violence was brought to England's own doors, and the fishing fleet was, more or less excusably, though of course unjustifiably, fired on at the Doggerbank as an operation of war, there was sudden and violent indignation. But the proceedings of the Russians in the Far East aroused no feeling whatever. The Earl of Balfour wrote able notes about them, and Mr. Hay wrote able notes about them, and Count Lamsdorff indited answers, and made promises, more or less well-observed, but the public remained apathetic. A letter addressed by the subscriber to the Daily Telegraph, calling attention to the alarming extension by Russia of the list of contraband, was denied insertion in its hospitable columns. The only effect of the Russian proceedings was to lead to their being partly legitimatized by the Declaration of London. That humiliating document

\footnotetext{
${ }^{10}$ For a discussion of the diplomatic incident, see 7 Moore, Dig. of Int. Law
} (1906) 739 , et seq. 
meekly accepted the Russian innovations, although they were supported by no shred of practice. It was defended in Britain substantially on the ground that if Continental Powers said a thing was lawful, Great Britain had no choice but to acquiesce, or to make the best bargain she could with them. Obviously, this is an argument which sweeps away international law altogether. If that law rests, not on instructed opinion and practice, but on the declarations of three or four continental governments, it ceases to be international, and becomes the municipal law of a world state. However, the British Government of the day agreed to (I) the wide extension of contraband (excluding, however, most raw material, with the important exceptions of fuel and foodstuffs) ; (2) the admission of the continuous voyage doctrine (but only in the case of "absolute", i.e., obviously warlike, contraband); (3) the belligerent power to sink neutral vessels. Paper safeguards were attached to these surrenders, but they could not fail to be worthless in practice, and at most they amounted to presenting the injured neutral merchant with a lawsuit. Again we remark that international law and prize law have got to be clear and simple. The absolute immunity of goods documented, and on a correct course, for netitral ports; the absolute immunity of ordinary goods documented, and on a correct course, for mercantile enemy ports; the absolute immunity from violent damage of ships under the neutral flag; these are clear and simple principles. The Declaration of London abolished them, substituting novel immunities subject to fine-spun qualifications, difficult to rebut and requiring the minute examination of evidence brought at great trouble and expense from the ends of the earth. Affecting to afford the neutral a measure of protection against the novel pretensions of Russia, instead of boldly denying them, it produced a complicated web of presumptions and intentions, which in reality deprived the neutral of all security, and invested with an air of presumptive propriety all the excesses of a belligerent. It yielded to "the ignorant and violent innovations of a bureaucratic despot accustomed to regard the merchantman as a cipher before the man-war."

Napoleon I at the height of his power and the extremity of his necessity, during the naval operations which culminated in Trafalgar, found it imperative to preserve absolute secrecy as to the whereabouts. of the Atlantic fleet. Vice-Admiral D'Allemand, its commander, sank without scruple allied Portuguese and Spanish vessels. But he dared not lift a finger against neutral Americans and neutral Swedes.. ${ }^{11} \mathrm{He}$ had to let them go their way-easy as it would have been to sink them and trump up a case of contraband against them, in which France could always have paid damages with cheerful content. . Never had a neutral ship been sunk by a belligerent. But because state-worshipping bureaucrats in Germany and Russia said that it

"Desbriere, Projets et Tentatives de Debarquement Aux Iles Brittanniques (I900); Baty, Britain and Sea Law (I9Ir). 
could be, Britain, forsooth, was to make the best terms she could with the new-fangled doctrine! This is not the place in which to examine the startling innovations of the Declaration of London in detail. Suffice it to say, that in essence it took away the security of the neutral trader and graciously presented him, with a first-class lawsuit in exchange.

But even this did not by any means fill up the cup of belligerent ambitions. In the German war, even the slender restrictions imposed by the Declaration of London went by the board. It had never been ratified by Great Britain, owing to the refusal of the House of Lords to enact the necessary legislation, and although she announced an intention of adhering to its terms, she repented of that announcement within two or three months. Although the Allies sank no neutral ships, the Germans did; and on the other hand, the Allies applied the dogma of continuous voyage and increased the list of contraband to such an exuberant extent as to supersede the institution of blockade. As they could not blockade the Baltic ports of Germany, this was their method of circumventing the difficult-to abandion the provisions of the Declaration which, as we have seen, more or less effectively prevented the application of the doctrine of continuous voyage to cargoes not obviously warlike, and excluded cotton, wool and rubber, along with metallic ores and certain chemicals and minerals, from the category of contraband altogether.

To assist the court in establishing the intentions and ultimate distinctions which would condemn, the established and imperative rules of evidence in Prize were abolished in Great Britain, and the ordinary system of trial substituted; in other words, the "primary evidence" coming "out of the ship's own mouth" ("ex ore tuo judicaberis") was disregarded, and the claimant was called upon to prove his innocence-an utter and gross departure from the principles of Prize. Those accepted principles excluded captor's evidence, and formed the justification for so violent an interference with friendly vessels as capture implies-the friend's vessels were not brought in to defend themselves; they were only brought in when they were self-condemned. (Of course any flaw in their documents or in the statements of their crews was immediately fatal.). This age-long security was lost; and by judicial action the neutral was actually forced to deposit a heavy pledge before he was admitted even to the attenuated privilege of endeavoring to prove his innocence before a tribunal in which his adversary was judge, prosecutor and witness all in one.

Such is the penalty of indifference. And, indeed, the modern sentiment of indifference to neutral maritime rights is remarkable. Few of us now can remember I86I. But we have all heard of the tempest which swept over England when southern envoys were then taken out of a British steamship; and we have all read the passion with which earlier in the century Americans rejected the claim of Great Britain 
to search American ships, be it for deserters or be it for silaves. The ship, in days not so long past, was conceived of as a floating prolongation of territory. In the inviolability of the territory she participated as long as she flew the flag. An assault on a national ship, unless it could be justified by the plainest precedents, touched the national honor. Somehow, we do not think in that way now.

When the Africa was seized by Italians in the Red Sea, and men were forcibly removed from under the British flag, in I9II, there was not the slightest ripple of that wave of emotion which surged up on the occasion of the stoppage of the Trent just 50 years before. Certainly she was only an Indian ship, owned by Parsis in Bombay; but when the Knight Commander, the Hipsang, the Ikhoma, and the Saint Kilda were sunk by the Russians in the Far East, there was not a glimmer of anger or annoyance in England; nor was there any particular feeling in America when the Germans ten years later sunk the $W . P$. Frye. The deep resentment caused by the German submarine campaign was due solely to humane condemnation of the loss of life involved; it was as acute when belligerent vessels were sunk as when neutrals were. Perhaps in Scandinavia and Holland alone was there any national sentiment aroused by the mere violence done to the neutral flag. This is really a curious, and a disquieting phenomenon, of which the causes are obscure, but of which the consequences may be extremely far-reaching. However it comes about, it seems to imply a carelessness for the national honor, and an insensitiveness to the inviolability of the national mercantile marine, not very consistent with a strong sense of national unity. Perhaps the explanation.may be true that in spite of all the talk about nationality and national solidarity, the mass of people generally are not now so proud and conscious of their nationality as they were fifty years ago. Cosmopolitanism is setting in with a stronger tide than many of us imagine, while, in conferences and congresses-

"The tired sea vainly breaking

"Seems here no painful inch to gain,-

"By distant creeks and channels making,

"Comes, silent, flooding in, the main."

Yet the world is organized on a basis of nationality, and it is difficult to see what is to take its place. If this straw shows which way the wind blows, and nationality is really, for all the academic and official talk, a spent force, we would seem to have approached the end of an age, and to be within measurable distance of either a cosmopolitan Utopia or a world plutocracy-the reader will have his own opinion which.

At any rate, it is undeniable, whatever be the explanation or the inferences, that there is no longer the same proud reliance on the inviolability of the national flag at sea that there was fifty years ago. 
Invasions of it are viewed with tolerance, if not with indifference. And, apart altogether from technical details of prize-law and procedure, that is a feature of recent thought which leads one to hoist a dangersignal. Invasions of rights, if they are to be successfully resisted, must be resisted at once. Otherwise they become privileges. The tendency of average indolent humanity is to murmur, "It. will not happen again" and, when it does happen again, "It will get no worse." But the thin end of the wedge inevitably does bring in the thick end, and the abuse does become inveterate, and does become enormous, until the cloud like a man's hand envelopes the skies and the heavens are swallowed up in tempest and thunderbolts.

No doubt we must move with the time. But there is nothing in that motion to lead us to permit belligerents to oppress neutrals. The problems of modern war may not be precisely the problems of eighteenth century war, but that is not a reason for sweeping away all the guarantees of neutral trade. Modern commerce may be complex; that is no reason for discarding the elementary rules of prize procedure. Modern communications may be rapid and good; that is no reason for permitting the virtual blockade of neutral ports. The most careful and elaborate inquiry as to the modifications of the problems of blockade and contraband introduced by modern conditions (such as the fast cruiser on the one hand and the railway on the other) would be requisite before the well-established rules of prize could be subverted. No pretense at such an inquiry has ever been made -much less have any conclusions been established. It is in pure ignorance that the common lawyers have been allowed to revolutionize the law of Prize in England and the bureaucratic lawyers to disregard it on the continent. The danger-signal must be hoisted lest the like end be accomplished in America.

The cases in which the departures from principle and precedent in English Prize practice are most strongly marked depend largely on the authority of Sir S. Evans. Sir S. Evans was purely a common law lawyer and an excellent advocate. He had gone the South Wales Circuit, and he was thoroughly at home in a case of bigamy or breach of contract. $\mathrm{He}$ was made President of the Probate Divorce and Admiralty Division because he had been a distinguished politician, but he was never understood to have any special acquaintance with international law, or the law of prize. It may be doubted whether he had ever heard of Phillimore's remark that it is a great mistake to confuse the common law notions with respect to evidence with those of the law of prize; or of Story, that the two have nothing in common. He tried every case as though it were a case to be tried on pleadings at assizes. He was not a great judge, nor even a good judge. Posterity will not rank him with Scott and Story and Portalis, but rather with such judges as Judge Betts and Sir James Marriott, whom indeed he greatly resembled in mentality. He was industrious, shrewd and alert, but opinionated, biased and impatient. Few indeed are the judgments 
among his reported decisions which are in favor of the neutral. Above all, he had no background of learning. He had laboriously acquired an acquaintance with many of the details of international law, but he had none of its atmosphere. This put him (like Chase) at the mercy of isolated texts. He had not the solid learning which would have enabled him to check them by reference to the general stream of authority. "There is no God," according to the Psalms; but an interpreter with some acquaintance with theology recognizes that this is a singular statement to find in the Bible, and proceeds to discover that the true proposition was that the fool had said so in his heart. Similarly, when Story, in Maisonnaire v. Keating ${ }^{12}$ said that the command of his sovereign was a justification everywhere to a captor, Sir Samuel failed to see that Story was speaking (as he so often did) with reference to the special circumstances before him at the moment (viz., the liability of a captor in tort), and by no means intending to lay down a general rule. Regardless of the universal consensus that neutral claimants must be afforded every facility for proving their case, seeing that their goods have been forcibly taken from them on the common highway of nations, he was responsible for the rule imposing a heavy security to be exacted before they could be allowed to ask for the recovery of their goods, as was their international right. Impressed by two or three dubious notes in an expert's manuscript prepared for a totally different purpose, Sir Samuel held that prize was seizable on land, oblivious of the fact that, had it been so, it must have been apparent in a hundred cases, and must have rendered the common law writs of devenerunt a dead letter. The true apostolic successor of Sir Leoline Jenkins and Lord Stowell was Lord Parker of Waddingtonand he, curiously enough, was a chancery judge, as little likely to be steeped in the principles of Prize as anybody. Had Lord Parker been judge of the prize court, we should have had some valuable applications of the old law to the new facts. Possibly, like Stowell in the Fox, ${ }^{13}$ he would have justified everything as "reprisals". That would, at least, have been in line with precedent, if not good precedent. Lord Parker was learned, courteous, patient and eminently impartial. $\mathrm{He}$ saw that the truest patriotism demanded the severest justice. "Son jugement," says M. Visscher, "est remarquable par la précision de sa doctrine, et la fermété de son argumentation."14

It has now become apparent that the Declaration of Paris, which was supposed to place the neutral carrier on a pinnacle of security and favor, has operated in exactly the reverse direction. It has resulted in the denaturalization of the conception of contraband, and in the brutalization of prize procedure. The neutral carrier of enemy goods, instead of getting freight from the captor, as before the Declaration,

12 (1815, C. C. D. Mass.) Fed. Cas. No. 8978.

${ }^{13}$ (I8I2) Ed. Adm. Rep. 3II.

14 (1920) 27 Rev. Gen. DE Droit Int. Pub. 32. 
now sees his ships and freight confiscated as engaged in contraband trade. The neutral importer to his own ports can never be safe from a similar imputation of contraband, and from ruinous lawsuits in a strange country in a strange language.

And the curious thing is that lawyers in the late belligerent countries of Europe really seem to expect neutrals to be satisfied with their decisions. Nothing struck me more forcibly, on a recent visit to Europe, than the assumption of so many Allied lawyers that belligerents are absolutely entitled to stop anything from reaching the enemy which may be of service to him and may take any steps which from time to time may be effective for that purpose. Such was never the case. Blockades were never expected or supposed to seal a whole country hermetically up. Iron was never contraband, nor were wagons-yet war could not have been carried on without them. There is no ground for the assumption that a belligerent's convenience must override all neutral security. I was wrong, a moment ago. What struck me more forcibly still was the calm assumption on all hands that because a court or a board of belligerents was honestly satisfied that goods had an enemy destination, neutrals must necessarily be satisfied too. "It was not impossible to form a very fair judgment whether goods were, or were not, going to the enemy," complacently observed one highlyplaced and influential official. And he evidently expected neutrals to be satisfied with this! Neutrals will not be satisfied with this: it is unreasonable to expect them to be. "You may be convinced of the enemy destination of the goods: we are not obliged to accept your convictions," is their obvious reply. It was amazing to find responsible persons, and many responsible persons, evidently clinging to the belief that all a belligerent had to do was to satisfy himself, and that neutrals must necessarily be content with this.

It was because neutrals will not be content with this, that the rules of Prize were established, making the evidence come "from the ship's own mouth." Some way will have to be found of restoring this security to neutrals. It may not be precisely the old way, and perhaps a system of official certificates issued by neutrals, such as were provided for in the Anglo-Swedish Treaties of I86I-4 (still binding between those powers in a European war) may prove in the end the most satisfactory substitute for the conclusiveness of ship's papers.

But, above all, the nations must recover a sense of the inviolability and sacredness of their ships. It is a sense which has been largely lost in the past forty years. The old dogma of the territorial character of merchant ships, accepted alike by Webster and Cavour, may be stigmatized as a fiction, but it did embody a real truth, did keep alive a real sentiment. It is not so fashionable as it was, but if neutral. rights are to be upheld, one does not see what single step could better contribute towards that end than to restore the currency and authority of that noble metaphor. 
Treaties.

In this department of the law of nations, also, matters are fast sliding into a quagmire.

Whose signature binds the nation? The answer used to be facile when monarchs embodied the nation. The signature of the monarch was necessary and sufficient. The usage spread to elective heads of states, but, in these days of ministerial power, has it spread to ministers? Writers would concur in saying not, but nothing is more frequent nowadays than agreements made between Foreign Ministers. Have these documents any, and what, force? It is difficult to see that they have any, particularly where the constitutional law of one or other state prescribes a special organ for the conclusion of treaties. In English constitutional law, the King is the sole depositary of the treaty power. In the United States it is the President with the advice and consent of the Senate. Instruments, by whatever name they may be called, made in the name of other organs of state, can only amount to non-binding expressions of intention, revocable at any moment, but useful until revoked, as a probable guide for the other party to follow. They are, in this light, comparable to the statements of intention exchanged by private persons for social purposes and without any view of creating legal relations. And yet, it is an extraordinary position that an instrument signed by the Minister charged with the conduct of foreign relations should not bind the state, at all costs, if the head of the state does not repudiate it. ${ }^{15}$

The Rush-Bagot arrangement, for instance, nobody can call a binding agreement. As a mutual statement of intention, it has been most beneficent in its operation. But not having been made by the President, or by the King, it has apparently no legal validity. The American occupation of Horseshoe Reef again in I850 can only be regarded as an occupation of territory left vacant by Great Britain. The memorandum embodying the arrangement, with the incidental correspondence, cannot have had the force of treaty. The power of the President to cede territory in this fashion, merely by permitting occupation by another cauntry, is worth examination from a constitutional point of view.

The question also arises, how far are constitutional restrictions on the power to make treaties operative as against foreign powers? It is never incumbent on states to study the constitutional law of other powers. This is conspicuously illustrated in the matter of according recognition to new governments. Their constitutionality or otherwise does not affect foreign countries. All they are concerned with is the patent fact of their supreme power. A foreign government cannot,

\footnotetext{
${ }^{15}$ A very funny instance is that of the British treaty with Socotra signed by a subordinate "on behalf of" the Resident at Aden. (I886) 77 British and Foreign State Papers 1269. It was expressed to be made by "the British Government" and was ratified by that of India!
} 
in fact, take upon itself the interpretation of the notoriously difficult constitutional law of another country. Either the constitutional provisions are written, in which case their interpretation is always ambiguous and disputable; or they are traditional, in which case nobody can interpret them except those who are steeped in the tradition,-although Calvo seems to think otherwise, ${ }^{16}$ and Heffter ${ }^{17}$ observes that constitutional provisions to be of international force must be "incontestés"-to be "incontestable" is not enough. "Dans les relations internationales, en effet, la possession seule peut être prise en considération."

The old rule of accepting the signature of the head of the state, and that only, involved as little difficulty as any. . The modern qualifica- tion of requiring the concurrence of two-thirds of the Senators present at a sitting of the Senate, in the United States, is so well-known and so well-established, that, in that special case, perhaps all nations may be said to be fixed with knowledge of it. But in general, and on principle, it ought to be held that the head of the state can alone bind a nation by treaty. It is childish to say that there may be no head of a state. There may be joint heads, but a state implies a government and in any government somebody presiding over that government there must be. There may be two, as in the case of William III and Mary II. There may be several, as perhaps was the case in the old Venetian Councils and with the States-General. But there must be somebody, and the acceptance of an envoy or commissioner as the agent of "the state" or "the government," in vague and impersonal terms, is open to the objection that a subsequent split in the "government" may enable it to be alleged that no proper authority was ever given. Certainly treaties exist which purport to be made between "governments" by their agents. But some person or persons must have signed, in such cases, the agents' full powers.

Is the signature sufficient which a foreign minister has expressly or implicitly declared sufficient? A foreign minister is the agent of the sovereign power to conduct foreign affairs. Must not an instrument signed by himself, or in a manner stated by him to be sufficient, be binding accordingly? The answer must, it is conceived, be in the negative. A foreign minister is not a general agent. He is rather in the position of the servant, and he has no authority to dispense with the requirement which is asserted to be universal, that the country can in general only be bound by the head or heads of a state. It is not forgotten that commanders in the field may bind the state within the limits of military conventions, as agents of necessity. ${ }^{18}$.

Can the nation, then, not contract to sell a cargo of coals to its neighbor without the sovereign's or the chief executive's sign-manual?

${ }^{10}$ Calvo, Le Droit International (1896) sec. I6I8.

${ }^{17}$ Op. cit. supra, note 6 , sec. 84 .

${ }^{18}$ Wilson v. Tumman (1843, C. P.) 6 Mann. \& G. 236; Watson v. Swann (I862) II C. B. (N. s.) 755 . 
Probably the answer is that petty transactions of this kind are within the scope of the various ministers and subordinate officials who are the sovereign's agents for minor purposes. Again, does the fact that a treaty, made without the chief's signature, has been acted upon by the other party without demur, give it validity by implied ratification? On principle, one would say not. From the beginning, the instrumente must have been regarded as incapable of creating legal rights. If it had been intended to bind the treaty-making power, the chief of state, it would have said so. Therefore, it is incapable of ratification. Should it be, in some instance, the fact that ministers, or parliaments, were so inept as to imagine that their own agreement bound their respective states, it would no doubt be possible for a case of ratification by the heads of states to arise.

The argument here put forward has, it is needless to say, nothing to do with a leaning to monarchism, or presidential republicanism, or any other form of government. It simply goes the length of saying that uncertainty in these matters is intolerable; that the rule has not been displaced according to which heads of states (i.e., if no historically well-recognized head of state exists, then the person or persons in supreme control) are alone internationally competent to bind states by treaty, convention or agreement. It may further be advanced that constitutional limitations on their power are useless unless notorious, or notified.

\section{General.}

It has been seen that a kind of sloppy vagueness, if we may use such colloquial terms, has been creeping into the relations of nations. On land, the clear-cut sentiment has been weakened, according to which invasion is necessarily war; and national safety and security have thereby been dangerously lessened. At sea, the inviolability of the national flag, respected even by Napoleon, has been whittled away, until a neutral only navigates the sea by sufferance. In the realm of contract, people are signing instruments purporting to bind the state, as to which it is more than likely that no legal weight can be attached.

All this is unjuridical and bad; bad for science, bad for peace, and bad for international law. The remedy, like the remedy for most things, is a change of heart, a return from the vague desire to manage things everywhere, to the firm resolve to manage things well at home. "Truly," says Carlyle, "if each of the Royal Majesties and Serene Highnesses would attend to his own affairs-doing his utmost to better his own land and people, in earthly and in heavenly respects a little,he would find it infinitely profitable for himself and for others. And balance of power would settle, in that case, as the laws of gravity ordered; which is its one method of settling, after all diplomacy. ". . . mind well your own affairs, leave those of your neighbors well alone," said Frederick the Great. But that is not a popular gospel to-day. 